STUDIA I ARTYKUєY

\title{
„Służba”, kapitalizm i „kosmopolityczny patriotyzm”: amerykański Czerwony Krzyż Młodzieży w II Rzeczypospolitej
}

\begin{abstract}
Abstrakt: Artykuł poświęcony jest działaniom amerykańskiego Czerwonego Krzyża Młodzieży w Polsce po I wojnie światowej. Przedstawiono w nim główne typy inicjatyw podejmowanych przez organizację w szkołach w II RP (m.in. zakładanie kół młodzieży, pomoc ubogim i nieuprzywilejowanym uczniom, wymiana listów w ramach międzynarodowej korespondencji międzyszkolnej). W artykule ukazano też idee wychowawcze i edukacyjne szerzone przez CKM, mające doprowadzić do znaczących zmian politycznych zarówno na gruncie lokalnym, jak i międzynarodowym.
\end{abstract}

Słowa kluczowe: Amerykański Czerwony Krzyż, Czerwony Krzyż Młodzieży, II RP, Stany Zjednoczone.

Abstract: The article is devoted to the operations of the American Junior Red Cross in Poland after the First World War. It describes the main types of initiatives undertaken by the organisation in schools of the Second Polish Republic (among others, the creation of circles of interest, aid to the poor and unprivileged students, or exchange of letters within the international interschool correspondence). The article also presents the educational ideals propagated by the American Junior Red Cross, which were to lead to significant political changes both at the national, and at the international level.

Keywords: American Red Cross, Junior Red Cross, the Second Polish Republic, the United States of America.

Po I wojnie światowej szereg amerykańskich organizacji humanitarnych i filantropijnych podjął próby udzielenia materialnego i instytucjonalnego wsparcia odradzającej się po latach zaborów i konfliktu zbrojnego Rzeczypospolitej. 
Wiele z tych inicjatyw kierowano do dzieci uważanych przez Amerykanów za najbardziej dotknięte skutkami wojny, takimi jak głód, choroby czy sieroctwo. Najmłodsi z II RP byli postrzegani przez działaczy społecznych z USA nie tylko jako najbardziej cierpiący segment polskiego społeczeństwa, lecz również jako przyszłość narodu, od którego miało zależeć przetrwanie demokracji i kapitalizmu na terenach rozciągających się pomiędzy Niemcami i Rosja Radziecką. Doraźna i bezpośrednia pomoc charakteryzująca amerykańskie inicjatywy humanitarne i filantropijne w Polsce w okresie międzywojennym łączyła się więc z szerzej zakrojonym projektem o charakterze politycznym.

Polityczne, i to w wymiarze globalnym, cele miała aktywność rozpoczęta po Wielkiej Wojnie w II RP przez przybyłych z USA liderów Czerwonego Krzyża Młodzieży (Junior Red Cross, dalej: CKM), organizacji stanowiącej przybudówkę Amerykańskiego Czerwonego Krzyża (American Red Cross, dalej: ACK) ${ }^{1}$. Głównym miejscem inicjatyw podejmowanych przez działaczy CKM stała się szkoła, szczególnie zaś placówki edukacyjne na najniższym, elementarnym poziomie, w których od początku lat dwudziestych XX w. organizacja zakładała koła młodzieży. Zrzeszeni w nich polscy uczniowie, podobnie jak dzieci w Stanach Zjednoczonych, podejmowali się wielu inicjatyw m.in. z dziedziny higieny szkolnej ${ }^{2}$. Oferowali także pomoc materialną uboższym od siebie kolegom oraz - przyjmując amerykańskie wzorce - wymieniali listy z dziewczynkami i chłopcami w innych krajach.

Pomoc, czy też „służba” innym, oraz międzynarodowa korespondencja międzyszkolna prowadzona przez dzieci w kołach młodzieży CKM stanowia dwie inicjatywy amerykańskiej organizacji, pozwalajace na przyjrzenie się i analizę politycznego wymiaru działań podejmowanych przez Amerykanów w powojennej Rzeczypospolitej. Spośród wszelkich działań humanitarystów i filantropów ze Stanów Zjednoczonych to CKM wyróżniał się spójnym, wyrazistym i długofalowym programem wychowawczym skierowanym do dzieci w wieku szkolnym. Możliwość podjęcia działań na gruncie polskich instytucji oświatowych była z punktu widzenia filantropów i aktywistów z USA szczególnie pożądana m.in. ze względu na siedmioletni obowiązek szkolny wprowadzony w II RP w lutym 1919 r., bardzo szybko po odrodzeniu się państwa polskiego ${ }^{3}$. Obejmując powinnością edukacyjną wszystkie dzieci

\footnotetext{
${ }^{1}$ Na temat działalności ACK w Europie Środkowo-Wschodniej, w tym w Polsce, po I wojnie światowej por. J.F. Irwin, Making the World Safe. The American Red Cross and the Nation's Humanitarian Awakening, Oxford-New York 2013, s. 151-184; F.R. Dulles, The American Red Cross. A History, New York 1950, s. 195-208.

2 J.F. Irwin, Teaching „Americanism with a World Perspective”. The Junior Red Cross in the U.S. Schools from 1917 to the 1920s, „History of Education Quarterly” 2013, vol. LIII, no. 3, s. 260; N. Tomes, The Gospel of Germs. Men, Women, and the Microbe in American Life, Cambridge 1999, s. 113-34; J.F. Hutchinson, The Junior Red Cross Goes to Healthland, „American Journal of Public Health” 1997, vol. LXXXVII, no. 11, s. 1816-1823.

${ }^{3}$ Dekret o obowiązku szkolnym odnosił się przede wszystkim do obszarów byłego zaboru rosyjskiego; w pozostałych administracje państwowe wprowadziły obowiązek szkolny przed
} 
w wieku od 7 do 14 lat, decydenci II Rzeczypospolitej stworzyli przy okazji podatny grunt do działań dla nastawionych reformistycznie humanitarystów z USA. Normy i wzorce szerzone przez obywateli USA w szeregach uczniów i uczennic aktywnych w kołach młodzieży były przekazywane także dorosłym lokalnym społecznikom i aktywistom, którzy po opuszczaniu II RP w 1923 r. przez ACK kontynuowali i rozszerzali działania organizacji z USA w ramach polskiego CKM.

W wieloetnicznym, niejednolitym i rozczłonkowanym przez wiele lat zaborów kraju, jaki stanowiła odrodzona w 1918 r. Polska, szkoła miała pełnić wiele istotnych ideowych i państwotwórczych zadań: scalających, jednoczących, a także modernizujących społeczeństwo ${ }^{4}$. W latach istnienia II Rzeczypospolitej różne opcje polityczne kładły nacisk na nieco odmienne cele szkoły jako instytucji publicznej. Dominująca do 1926 r. endecja widziała w placówkach edukacyjnych przede wszystkim miejsce kształcenia patriotycznego, budowania i przekazywania wspólnej tradycji narodowej, wzmacniania postawy religijnej. Program ten, tak naprawdę nigdy do końca niewprowadzony, określany jest zazwyczaj przez historyków edukacji jako „wychowanie narodowe”. Stanowiło ono realizację kierunku narodowo-chrześcijańskiego w ideologii pedagogicznej okresu międzywojnia. Po przewrocie majowym do głosu w większym stopniu doszli zwolennicy nurtu demokratyczno-obywatelskiego, propagujacy „wychowanie państwowe", majace doprowadzić do wzmocnienia w uczniach i uczennicach poczucia obywatelskości i przynależności państwowej niezależnie od pochodzenia etnicznego czy wyznawanej religii ${ }^{5}$. Skierowane do szkół w II RP inicjatywy filantropów z ACK odbywały się przede wszystkim w pierwszym z tych okresów. Miejscowe organizacje i lokalni liderzy kontynuowali je przez całe międzywojnie. Czy wywodzące się ze Stanów Zjednoczonych pomysły były zgodne z wizja „wychowania narodowego”, „wychowania państwowego”, czy też miały na celu przeniesienie na polski grunt odmiennych ideałów pedagogicznych? Między innymi na to pytanie postaram się odpowiedzieć w niniejszym artykule.

Dzieje założenia i pierwszych lat funkcjonowania CKM w USA sa historia niebywałego sukcesu. W 1918 r., zaledwie rok po jej stworzeniu, organizacja liczyła $11 \mathrm{mln}$ członków, czyli ok. połowę całej populacji uczniów i uczennic w Stanach Zjednoczonych. Amerykańskie stowarzyszenie wyróżniało działanie wyłacznie poprzez szkoły postrzegane jako instytucje melioryzmu

1914 r. Pomimo wysiłków władz praktyczna realizacja dekretu napotykała przez całe dwudziestolecie międzywojenne przeszkody, a do 1939 r. nie udało się objąć obowiązkiem szkolnym wszystkich dzieci żyjących na terenach II Rzeczypospolitej. Dokładne wartości dotyczące realizacji obowiązu szkolnego podaje np.: J. Schoenbrenner, Walka o demokratyczna szkote polska w latach 1918-1922, Warszawa 1963, s. 218-227.

${ }^{4}$ J. Sadowska, Ku szkole na miare Drugiej Rzeczypospolitej. Geneza, założenia i realizacja reformy Jędrzejewiczowskiej, Białystok 2001, s. 7.

${ }_{5}^{5}$ F.W. Araszkiewicz, Ideaty wychowawcze Drugiej Rzeczpospolitej, Warszawa 1978, s. 89-92. 
społecznego. Doskonalenie dzieci w wieku szkolnym według działaczy CKM miało się odbywać w ramach wspomnianych już kół młodzieży zakładanych w placówkach oświatowych ${ }^{6}$.

W II Rzeczypospolitej CKM zaczą działać wkrótce po przybyciu ACK do kraju dotkniętego skutkami wojny. Pierwszym miejscem jego aktywności stał się sierociniec założony w styczniu 1920 r. przez Amerykanów w Białymstoku. Przybyli na Podlasie działacze CKM rozpoczęli w nim modelowy, szeroko zakrojony program wychowawczo-rekreacyjny, zapewniając dzieciom możliwość pożytecznego spędzania czasu dzięki zajęciom, takim jak ćwiczenia na świeżym powietrzu, czytanie książek, wyplatanie koszy, robienie na drutach czy też nauka stolarki dla starszych podopiecznych płci męskiej ${ }^{7}$ Następne kroki podjęte przez CKM w większym stopniu przypominały działania organizacji w Stanach Zjednoczonych, gdzie najważniejszym przejawem jej aktywności było zakładanie kół młodzieży w szkołach. Niekiedy powstawały one również $\mathrm{w}$ innych placówkach, takich jak ochronki, odbiegając $\mathrm{w}$ tym aspekcie od amerykańskiego pierwowzoru.

Z wyborem szkół jako miejsc działania kół młodzieży łączyła się pewna filozofia. Charakteryzowała ja wizja szkoły jako miejsca optymalnego do podejmowania pożądanych inicjatyw wychowawczych, skierowanych do dzieci znajdujacych się w wyjątkowo sprzyjającym ku temu wieku. Jednym z celów projektów edukacyjnych podejmowanych przez CKM było zapewnienie najmłodszym „normalnego dzieciństwa”. Termin ten, używany w działalności organizacji przez okres całego międzywojnia, powstał właśnie w kręgach CKM. Idea i ideał „normalnego dzieciństwa” czy też „normalnego wychowania" stanowiły odpowiedź na czasy Wielkiej Wojny i jej negatywne skutki widoczne na ciałach i w umysłach europejskich dzieci. Miały one na celu umożliwienie najmłodszym doświadczenia szeregu aktywności, praktyk i przeżyć uważanych przez amerykańskie elity za niezbędne dla „normalnego” rozwoju i wychowania. „Normalność” i „normy”, podobnie jak w przypadku innych amerykańskich inicjatyw filantropijnych, definiowane były zgodnie z ideałami białej, anglosaskiej klasy średniej zamieszkującej ówcześnie USA. Według propagatorów „normalnego wychowania” z CKM, poprzez zaplanowane inicjatywy edukacyjne, higieniczne i rekreacyjne, powojenne pokolenie europejskich dzieci miało wyrosnąć na generację inną niż ich rodzice, postrzegani jako osoby odpowiedzialne za wybuch światowego konfliktu zbrojnego ${ }^{8}$. „Normalne wychowanie” powinno jednakże polegać nie tylko na stworzeniu,

\footnotetext{
${ }_{6}^{6}$ J.F. Irwin, Teaching „Americanism with a World Perspective”..., s. 255, 258, 278; B. Little, A Child's Army of Millions. The American Junior Red Cross, w: Children's Literature and Culture of the First World War, ed. L. Paul et al., New York-London 2015, s. 283-300.

${ }^{7}$ National Archives and Records Administration, College Park, MA (dalej: NARA), Records of the American Red Cross (dalej: ARC), box 862, folder 947.11/08, Poland (Dec 1920), s. 1-2.

8 J.F. Irwin, Sauvons les Bébés. Child Health and U.S. Humanitarian Aid in First World War Era, „Bulletin of the History of Medicine” 2012, vol. LXXXVI, no. 1, s. 55-56.
} 
poprzez kulturę fizyczną i higienę szkolna, zdrowego i silnego pokolenia. Równie ważny, i poniekąd sprężony z tym pierwszym, był czynnik wychowawczo-edukacyjny: zaszczepienie wśród dzieci w wieku szkolnym wybranego światopoglądu i wzorca zachowań.

Filozofię wychowania, którą według liderów CKM ze Stanów Zjednoczonych należało przenieść do państw powojennej Europy, propagatorzy kół młodzieży określali jako „służbę” (service). „Służba” nieprzypadkowo stała się mottem działań młodzieżowej przybudówki ACK założonej w momencie angażowania się Stanów Zjednoczonych w globalny konflikt zbrojny, który okazał się wojna totalną wymagajacca włączenia całego społeczeństwa. Na wzór amerykańskich żołnierzy służ ący ch na froncie za oceanem, na froncie domowym miały służyć, poprzez włączanie się w prace kół młodzieży, amerykańskie dzieci w wieku szkolnym. Ta konotacja, zamierzona przy używaniu słowa „służba”, może też tłumaczyć nagły spadek popularności CKM w USA po Wielkiej Wojnie. Amerykańskie społeczeństwo, zmęczone wojną i pragnące zgodnie z hasłem prezydenta Warrena Hardinga „powrotu do normalności”, przestało po wojnie entuzjastycznie reagować na apele zaangażowania się na rzecz innych i uczestnictwa w inicjatywach humanitarnych ${ }^{9}$. Mniejsza chęć do tego, by „służyć innym”, doprowadziła do trzykrotnego spadku liczby członków kół młodzieży w amerykańskich szkołach w czasie zaledwie kilku lat po wojnie. Po 1919 r. idea służby społeczeństwu i krajowi wydawała się bardziej przystająca do sytuacji i potrzeb w powojennej Rzeczypospolitej, gdzie nieuprzywilejowane finansowo dzieci mogły odnieść wielką korzyść z pomocy swoich lepiej sytuowanych rówieśników.

Świadomi wielorakiego znaczenia wyrazu „służba” w języku polskim, wręcz ostrzegani o możliwym niepowodzeniu komunikacyjnym, Amerykanie zdecydowali się jednak na jego używanie w II RP. Słowo „służyć” pojawiło się w haśle głównej inicjatywy z zakresu higieny szkolnej propagowanej przez organizację, tzw. gry o zdrowie, głoszacym, że „Najlepszymi obywatelami sa ci, którzy najlepiej służą [innym - S.K.M.]. Aby służyć dobrze, trzeba mieć dobre zdrowie"10. Popularyzując CKM wśród warszawskich uczniów, inicjatorzy kół podkreślali, że celem organizacji jest: „służenie rodzinie, społeczności, krajowi, oraz całemu światu” ${ }^{11}$. Hasła o „służeniu” innym wykorzystywano zaś szczególnie często na pierwszym etapie działalności CKM w powojennej Polsce.

Najwcześniejszą formą aktywności amerykańskiego stowarzyszenia w II RP stała się pomoc materialna oferowana przez członków kół młodzieży ubogim i potrzebującym rówieśnikom. Pierwsze grupy „Juniorów”, zakładane od jesieni

\footnotetext{
${ }_{9}$ Na temat „powrotu do normalności” i prezydentury Warrena Hardinga zob. R.K. Murray, The Politics of Normalcy. Governmental Theory and Practice in the Harding-Coolidge Era, New York 1973.

${ }^{10}$ NARA, ARC, box 862, folder 947.11/08, Score cards: Circles of the Polish Junior Red Cross.

${ }^{11}$ Ibidem, Address published by the Committee of P. and P. of the J.P.R.C. of Warsaw.
} 
1920 r. w porozumieniu z PCK, powstawały w szkołach byłej Kongresówki i w Galicji - na terenach najbardziej dotkniętych skutkami wojennych i powojennych katastrof i trudności ${ }^{12}$. W centralnej i wschodniej Polsce uczniowie zrzeszeni w kołach młodzieży zbierali fundusze na potrzebujące ubogie dzieci oraz na swoich rówieśników umieszczonych w instytucjach opieki, takich jak sierocińce. Dzięki zgromadzonym środkom wysyłano biedne dzieci na wieś, a chore na kolonie lecznicze. Częstym typem aktywności kół młodzieży była produkcja ubrań, na początku lat dwudziestych XX w. wciąż brakujących w Polsce. Zrobione na drutach rękawice i swetry oraz uszyte koszulki oddawano dzieciom w szpitalach, sierocińcach oraz najmłodszym korzystajacym z placówek prowadzonych przez ACK. W wielu miejscowościach aktywność podejmowana przez „Juniorów” miała służyć ambulatoriom i stacjom opieki nad niemowlętami ACK. Uczniowie pomagali w przychodniach, przyprowadzali do nich młodsze dzieci, wyposażali je w chodniki i szyli wyprawki dla niemowląt. W oddalonym o kilkadziesiąt kilometrów od Lwowa Złoczowie członkowie koła młodzieży kupili krowę w celu zaopatrywania w mleko stacji opieki nad matką i dzieckiem. Pomoc ta była, jak widzimy, bardzo praktyczna oraz wymierna i w wydatny sposób wspomagała inne inicjatywy amerykańskiej organizacji humanitarnej ${ }^{13}$. Według amerykańskich sprawozdawców przy każdym przejawie aktywności pamiętano o nadrzędnej idei wychowawczej. Na przykład podczas przygotowywania odzieży dla potrzebujacych dzieci w Lublinie „Juniorzy” „poznawali [także - S.K.M.] przyjemność służenia [innym]” ${ }^{14}$.

Pomoc materialna ofiarowana przez członków kół młodzieży swoim rówieśnikom, poza praktycznym wymiarem, miała również przyczynić się do zmiany perspektywy oraz usytuowania polskich dzieci, które od momentu zakończenia wojny były wspomagane przez humanitarystów z krajów Europy Zachodniej i Ameryki Północnej, zwłaszcza zaś ze Stanów Zjednoczonych. Poprzez aktywność w „Juniorach” dzieci z II RP przestawały być pasywnymi, bioracymi od innych adresatami pomocy. Stawały się natomiast aktywnymi podmiotami ofiarującymi i dającymi coś swoim rówieśnikom. Według amerykańskiej organizacji polskie dzieci poprzez działania w kołach młodzieży mogły poczuć własne sprawstwo jako wytwórcy (np. ubrań) czy osoby ofiarujące pomoc (np. pieniężna) innym ${ }^{15}$. Jednocześnie humanitaryści z USA podkreślali, że dawanie nie wymagało uprzywilejowanej sytuacji finansowej obdarowującego. Praktycznie każde dziecko było zdolne do pomocy i zaangażowania, przede wszystkim poprzez wytwory własnych rąk. Tylko jeden raz w trakcie kilkuletniego zaangażowania w II Rzeczypospolitej amerykańscy

12 Ibidem, Pro Memoria, s. 1; ibidem, Poland (Dec 1920), s. 1-2.

${ }^{13}$ Ibidem, Junior Red Cross Reports from the Field, April 5, 1922, s. 2-4; ibidem, Junior Red Cross, Złoczów, April 9, 1922; ibidem, Montly report, Junior Red Cross, April 1922; ibidem, Report Junior Red Cross, April $1^{\text {st }}$ to $30^{\text {th }}$ incl. (1922).

${ }^{14}$ Ibidem, Monthly report of Junior Red Cross, Feb 1922, s. 2.

${ }^{15}$ Ibidem, Junior Red Cross, Sept 1921. 
społecznicy zetknęli się z grupą dzieci niebędącą w ich mniemaniu w stanie „służyć” czy też pomagać innym. Chodziło o 80 sierot z ochronki w Kobryniu w województwie poleskim: wynędzniałych, bosych, trzęsacych się z zimna w nieopalonej placówce. Na ich widok pracownica społeczna ACK poczuła, że „[te sieroty] nie moga zostać poproszone, by służyć innym, bardziej nieszczęśliwym niż one same"16.

Polscy popularyzatorzy kół młodzieży nie używali jednak w kontekście swych działań terminu ,służba”, propagowanego przez Amerykanów. W II RP termin ten nadal kojarzył się z płatna pomoca domowa. Lokalni działacze, także w kolejnych latach aktywności kół młodzieży rozwijajacych się pod egidą PCK, na swych sztandarach „nosili” przede wszystkim hasło „czynu”, podkreślające aktywne zaangażowanie się ich członków w kwestie istotne dla ich społeczności ${ }^{17}$. Miejscowi propagatorzy kół młodzieży odwoływali się również do bliskich miejscowej kulturze koncepcji miłości bliźniego i altruizmu oraz etyki zaangażowania na rzecz innych, obecnej w kręgach Czerwonego Krzyża zarówno w USA, jak i w II Rzeczypospolitej. Popularyzatorzy kół w II RP byli przekonani o konieczności naprawy moralnej polskiego społeczeństwa, w przypadku którego wojna miała przyczynić się do obniżenia standardów etycznych. Poglądy te wybrzmiewały m.in. podczas spotkania założycielskiego CKM we Lwowie. Wypowiedź jednego z uczestników na temat pożądanych koncepcji i działań wychowawczych relacjonowała prasa lokalna:

Od najmłodszych lat trzeba, żeby dziecko pojęło, że życie nie polega na tym, by tylko o sobie myśleć i starać się zdobyć największą sumę dobra tylko dla siebie, ale że należy także pamiętać o tych potrzebujących pomocy. Niech dziecko część swoich wolnych chwil ofiaruje biedniejszym dzieciom, niech robi robótki, zabawki, a potem ofiaruje, a widząc radość obdarowanego, niech ma w niej szlachetną nagroda za swoje trudy ${ }^{18}$.

Amerykańskie źródła wytworzone przez CKM mówią o entuzjastycznym przyjęciu idei edukacyjnych stowarzyszenia w niektórych miejscach w Polsce. Pokazują one, że za sukces nierzadko odpowiadał lokalny rzutki działacz zaangażowany $\mathrm{w}$ przenoszenie koncepcji na macierzysty grunt. We Lwowie taka osobą był inspektor szkolny podkreślajacy potrzebę wychowania miejscowych dzieci na „ludzi wiedzących jak pomagać i jak osiagać wielkie cele za pomocą małych środków"19. Propagowanie idei służenia innym było z kolei

${ }^{16}$ Ibidem, Monthly report for October (1922), Poland, s. 2.

${ }_{17}$ Młodzież Polskiego Czerwonego Krzyża w Czynie. Jednodniówka wydana przez Warszawska Komisję Okręgowa Kót Młodzieży Polskiego Czerwonego Krzyża, Warszawa 1930.

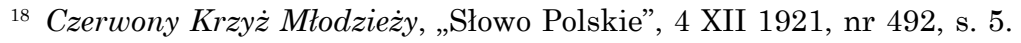

19 NARA, ARC, box 862, folder 947.11/08, Circular, from the School Inspector of Lwow District, subject: Junior Red Cross, Jan 28, 1922, s. 1-2. Lwowskie koła młodzieży były również najliczniejsze i najbardziej aktywne w kolejnych latach organizacji. W 1936 r. liczba ich członków wynosiła ok. 10 tys. Nasza praca. W 15-lecie istnienia kót młodzieży Polskiego Czerwonego Krzyża, Warszawa 1936, s. 14. 
na pewno trudniejsze w szkołach i społecznościach niechętnych „Juniorom”, nieprzychylnym okiem patrzących na organizację traktowana jako obca pomimo bliskości polskich i amerykańskich koncepcji wychowawczych.

Bliższe przyjrzenie się pomocy materialnej i „służbie” propagowanej w ramach działań kół młodzieży Czerwonego Krzyża pozwala dostrzec jeszcze jeden pożądany ideowy element całego przedsięwzięcia. CKM szerzył nie tylko miłość bliźniego, podmiotowość i sprawstwo. Poprzez pomocowe działania polscy „Juniorzy” mieli również „nasiąkać” pochodząca z USA kapitalistyczną etyką wytwórczości i oszczędności. Jej pierwszy omówiony już element kładł nacisk na produkcję dóbr pracą własnych rąk: poprzez robótki ręczne, szycie czy też uprawę przyszkolnych ogródków warzywnych ${ }^{20}$. Był on propagowany w ówczesnych Stanach Zjednoczonych w opozycji do rodzącego się w latach dwudziestych XX w. ducha konsumpcjonizmu. Pracując $\mathrm{w}$ warzywniku czy robiąc na drutach rękawice, amerykańskie dzieci, szczególnie te z miast, miały wykształcić w sobie tradycyjna ,etykę wytwórcy” (ethic of producer), ukazywana jako przeciwwaga dla postaw konsumpcjonistycznych. Produkując samodzielnie żywność czy ubrania, dzieci zamieszkujace uprzemysłowione metropolie mogły wyrobić w sobie atrybuty cenione przez edukatorów i reformatorów wyrastających z XIX-wiecznej przedprzemysłowej tradycji intelektualnej. Jak pokazuja badacze, w trzeciej dekadzie $\mathrm{XX}$ w. idee te już jednak odchodziły w przeszłość, o czym świadczy nagły spadek popularności ogródków przyszkolnych w międzywojennych Stanach Zjednoczonych znajdujacych się w coraz większym stopniu pod wpływem kultury konsumeryzmu ${ }^{21}$.

W wysokim stopniu problematyczny był również powojenny transfer idei wypływających z koncepcji wytwórczości, przenoszonych przez CKM do Polski z USA. Główny powód rozmijania się amerykańskiego sposobu myślenia z lokalnymi polskimi warunkami stanowił niski stopień rozwoju ekonomicznego II Rzeczypospolitej. W powojennej Polsce dzięki robótkom ręcznym i przyszkolnym warzywniakom uczniowie osiagali przede wszystkim wymierne korzyści materialne. Uprawiając marchew, ziemniaki, fasolę czy buraki, dzieci zapewniały sobie chociaż w jakimś stopniu racje żywnościowe

${ }^{20} \mathrm{Na}$ temat ogródków przyszkolnych w USA zob. Ch.B. Damrow, 'Every Child in a Garden'. Radishes, Avocado Pits, and the Education of American Children in the 20th Century, niepublikowana praca doktorska, University of Wisconsin, Madison 2005, passim; S.G. Kohlstedt, „A Better Crop of Boys and Girls”. The School Gardening Movement, 1890-1920, „History of Education Quarterly” 2008, vol. XLVIII, no. 1, s. 58-93. O warzywniakach zakładanych w ramach aktywności amerykańskiego CKM w II RP zob. NARA, ARC, box 862, folder 947.11/08, Poland (Dec 1920), s. 4-5; ibidem, Pro Memoria, s. 5.

${ }^{21}$ R. Hayden-Smith, „Soldiers of the Soil”. The Work of the United States School Garden Army during World War, „Applied Environmental Education and Communication” 2007, vol. VI, no. 1, s. 19-29; B. Trelstad, Little Machines in Their Gardens. A History of School Gardens in America, 1891-1920, „Landscape Journal” 1997, vol. XVI, no. 2, s. 161-173. 
w okresie permanentnego i powszechnego powojennego niedożywienia. Praktyczny i finansowy wymiar bez wątpienia zdominował praktyczną realizację idei zakładania ogródków szkolnych propagowanych w II RP przez organizację ze Stanów Zjednoczonych. Historia tej inicjatywy wskazuje na bardzo głębokie różnice w sytuacji obu krajów. W jednym z nich starano się przeciwdziałać rosnacym tendencjom konsumpcjonistycznym, w drugim, kilka lat po wojnie, dzieci same musiały wyhodować produkty żywnościowe, by mogły je literalnie ,skonsumować”.

Łatwiejsze wydawało się z kolei przeniesienie na polski grunt etyki oszczędności, kluczowego elementu powstawania amerykańskiego kapitalizmu ${ }^{22}$. Zgodnie z nią miejscowi „Juniorzy” mieli pomagać swoim rówieśnikom nie tylko dzięki „kieszonkowemu” od rodziców, lecz przede wszystkim za pomoca „zebranych przez siebie indywidulanie i zbiorowo pieniędzy z przeznaczeniem na wybrany cel"23. Członkowie kół młodzieży razem decydowali na co przeznaczyć zebrane środki oraz prowadzili rachunki. Ponadto zobligowani byli do wnoszenia niewielkich składek członkowskich w wysokości pięciu marek, majacych stanowić przejaw niezbędnego dzieciom „poświęcenia się i wyrzeczenia”24. Finansowy wymiar działania „Juniorów” winien więc przygotowywać najmłodszych do aktywności (m.in. zawodowej) w gospodarce kapitalistycznej: zarabiania, wydawania i oszczędzania pieniędzy. Wpajając polskim uczniom wartości istotne dla wolnorynkowej ekonomii: gospodarność, przedsiębiorczość i wytwórczość, amerykańscy humanitaryści starali się zapewnić przetrwanie kapitalizmu w kraju graniczacym z komunistycznym Związkiem Radzieckim.

Idee związane z gospodarką wolnorynkowa Amerykanie z CKM propagowali również w ramach pomysłów na szkolnictwo zawodowe w Polsce. Organizacja wspomagała finansowo i logistycznie działające już w II RP placówki oraz sama inicjowała programy edukacyjne w tym zakresie, zarówno w szkołach, jak i w ochronkach. Przydatnych zawodowo umiejętności uczono np. we „wzorcowym sierocińcu" w Liskowie na południu Polski, przy którym otworzono szkołę handlową i rolniczą. Inicjatywy zawodowe CKM pozwalają również przyjrzeć się kwestiom związanym z różnica płciowa. Ucząc ubogie dzieci potrzebnych im umiejętności, Amerykanie zwykle szkolili chłopców w takich czynnościach, jak stolarka, praca w warsztacie, elementy mechaniki, rzeźbienie w drewnie. Dziewczynki natomiast miały się specjalizować w szyciu, tkaniu czy robieniu na drutach. Ten - na pierwszy rzut oka - tradycyjny podział czynności ze względu na płeć ${ }^{25}$ był jednak często przekraczany ze względów

${ }^{22}$ M. Weber, Etyka protestancka a duch kapitalizmu, tłum. B. Baran, P. Miziński, Warszawa 2010.

${ }^{23}$ NARA, ARC, box 862, folder 947.11/08, Address published by the Committee of P. and P. of the J.P.R.C. of Warsaw

${ }^{24}$ Ibidem, Poland (Dec 1920), s. 6.

${ }^{25}$ Amerykańskie koncepcje i poglądy na temat podziału pracy ze względu na płeć i związanych z tym przekonań dotyczących edukacji podzielane były przez polskich współpracowników 
praktycznych i finansowych. W Liskowie, jak opisywała jedna z pracownic ACK: „i chłopcy także, zdając sobie sprawę z braków odzieży w całym kraju, bez pogardy chwytaja za druty. Wiele z nich nosi szaliki, swetry i skarpetki, które sami zrobili. Za pieniądze zarobione ze sprzedaży owoców swojej pracy kupują materiały by wyprodukować więcej wyrobów" 26 .

Traktując jako oczywistą kwestię płciowego podziału prac i przyznając, że robienie na drutach mogłoby (w normalnych warunkach) spotkać się z „pogardą" chłopców, amerykańska sprawozdawczyni dawała jednak zgodę na transgresję płciową usprawiedliwiona specyficzna powojenna sytuacja w Polsce. W kontekście biedy i braków w zaopatrzeniu ważniejsze, niż wykonywanie „męskich” czynności, stawały się produktywność, pracowitość, wytwórczość, a nawet pewna „żyłka przedsiębiorczości”, którą cechowali się inwestujący w nowe materiały chłopcy. Zarabiając dzięki swojej pracy pieniądze i poznając działanie rynku, stawali się oni nadzieją na umocnienie kapitalizmu w II RP.

Czy wolnorynkowa etyka pracy była osiagalna także dla dziewczynek (i kobiet)? Czy i dla nich przewidziano rolę w rozwoju polskiego kapitalizmu i gospodarki przemysłowej? Można spróbować odpowiedzieć na te pytania, przyglądając się innym inicjatywom zawodowym CKM. Planując w $1923 \mathrm{r}$. program „Juniorów” na kolejne miesiące, amerykańska działaczka społeczna związana z organizacją Jane Howarth proponowała uczynienie z warsztatu tkackiego narzędzia zapewniającego kobietom utrzymanie „na kolejnych dziesięć lat”27. W wypowiedzi Howarth można znaleźć kilka interesujacych tropów badawczych. Z jednej strony w czasach wojny o niepodległość krosna były w Stanach Zjednoczonych uznawane za symbol „niewieściej” pracy ${ }^{28}$, a przędzenie i tkanie funkcjonowało w końcu XVII i na początku XIX w. jako czynność pozwalająca na pogodzenie ze sobą zarabiania pieniędzy oraz opieki nad domem i dziećmi przez kobiety potrzebujące zasobów finansowych ${ }^{29}$. Tkactwo domowe skończyło się jednak w Stanach Zjednoczonych w pierwszej

CKM, przede wszystkim zaś największego entuzjastę kół młodzieży - Kazimierza Kujawskiego. Jeszcze przed zakończeniem I wojny światowej deklarował on z jednej strony, że nie można stosować ograniczeń w wykształceniu dla kobiet, z drugiej jednak podkreślał, że „kobiety przeważnie mają w życiu inne obowiązki niż mężczyźni. Jeśli nie każdy mężczyzna może kończyć szkołę wyższa, to tym bardziej nie każda kobieta uczynić to może. Kobieta powinna mieć jednak ogólne wykształcenie, by mogła spełniać swoje najważniejsze zadania: matki oraz "człowieka-obywatela»". K. Kujawski, Projekt systemu szkolnictwa w Polsce. 1917, Warszawa 1917, s. 13.

${ }^{26}$ NARA, ARC, box 862, folder 947.11/08, Lisków orphanage, s. 3.

${ }^{27}$ Ibidem, folder 947.11/01, Jane Howarth (field director, JARC, Poland) to R.P. Lane (European Director, JARC), Feb 8, 1923, s. 3.

${ }^{28}$ M.B. Norton, Liberty's Daughters. The Revolutionary Experience of American Women, 1750-1800, Ithaca, NY 1996, s. 15 i n.

${ }^{29}$ A. Kessler-Harris, Out to Work. A History of Wage-Earning Women in the United States, New York-London 2003, s. 24, 66. 
połowie XIX w., po jego przejęciu początkowo przez manufaktury, a następnie fabryki. Proces ten pociagnął za sobą zmianę miejsca zarobkowania kobiet z domu na zakład produkcyjny. Wprowadził jednocześnie nienormatywność pracy zawodowej kobiet zamężnych i posiadających dzieci, pogląd propagowany szczególnie wśród warstw średnich amerykańskiego społeczeństwa. Przemiany te były społecznymi i ekonomicznymi reperkusjami rewolucji przemysłowej w Stanach Zjednoczonych.

Powojenna sytuacja w Polsce oraz rozwój gospodarki w Rzeczypospolitej wyglądały - także według Amerykanów - całkowicie inaczej. Według Howarth również w II RP miały nadejść czasy, kiedy całe tkactwo i produkcja ubrań zaczną być wykonywane w fabrykach. Jednak przez kolejnych 10 lat, czyli do połowy lat trzydziestych XX w., domowe krosna mogły zapewniać polskim kobietom utrzymanie. Amerykańska pracownica społeczna tak opisywała swój projekt:

każdej społeczności możemy dać tylko jeden warsztat tkacki, który może zostać użyty jako model, inne moga zostać zrobione na jego wzór. Jeśli można by wdrożyć plan organizacyjny, i starsze siostry i matki mogłyby przychodzić do szkoły po zajęciach, wieczorami, to myślę, że byłby to świetny pomysł. Ten rodzaj pomocy dałby im, jestem pewna, nową nadzieję ${ }^{30}$.

W polskiej uprzemysławiającej się dopiero gospodarce krosna miały być nie tylko wykorzystywane do uczenia tkactwa dziewczynek. Pomysł na pracę zarobkową kobiet powinien emanować ze szkoły na zewnątrz: do matek i starszych sióstr uczennic. Dzięki czynności możliwej do wykonania w domu polskie kobiety - przedstawiane zazwyczaj przez Amerykanów jako owdowiałe, jedyne żywicielki pozbawionych ojców rodzin - mogły godzić obowiązi rodzicielskie i domowe z potrzebą zarabiania pieniędzy. Pomysł przedstawiony przez pracownicę społeczną miał również istotny wymiar emocjonalny: dając „nową nadzieję”, przyczyniałby się do polepszenia kondycji psychicznej polskich kobiet borykających się z troskami życia codziennego. Inicjatywa Howarth i jej wypowiedź odnoszą się do rozwoju gospodarczego II Rzeczypospolitej: uznała go za kompatybilny z etapem, w którym Stany Zjednoczone znajdowały się sto lat wcześniej. Zgodnie $\mathrm{z}$ tą diagnozą został zaproponowany także typ szkolnictwa zawodowego dla dziewcząt i pracy zarobkowej dla ich matek.

Według projektów CKM zawody dla dziewczynek nie sprowadzały się jednak tylko do tkactwa. Zdaniem amerykańskich działaczy i decydentów „Juniorów” odpowiednią dla płci żeńskiej czynnością zarobkową było również ogrodnictwo i rolnictwo. CKM, jak już wspominałam, propagował ideę ogródków przyszkolnych, w których uczniowie mieli uprawiać warzywa. Ogrodnictwo,

${ }^{30}$ NARA, ARC, box 862, folder 947.11/01, Jane Howarth (field director, JARC, Poland) to R.P. Lane (European Director, JARC), Feb 8, 1923, s. 3. 
a nawet instruktaż prawidłowych praktyk rolniczych mogły przyczynić się do przyszłych karier zawodowych grupki dziewcząt ze szkoły rolniczej nieopodal Wilna, gdzie na początku lat dwudziestych XX w. powstało koło młodzieży. Uczennice z tej placówki - jak planował jeden ze sprawozdawców CKM mogły po skończeniu szkoły zostać wysłane jako nauczycielki i instruktorki $\mathrm{w}$ teren, aby uczyć w małych wioskach prawidłowych praktyk oraz technik ogrodniczych i rolniczych ${ }^{31}$. Stawiając za wzór podobny program prowadzony przez amerykańskie szkoły wyższe, zapoczątkowany na większą skalę przez Uniwersytet w Wisconsin, Amerykanie odwoływali się do idei wyrastającej z samego pnia progresywizmu ${ }^{32}$. Nawołujacc do „rozszerzenia” (extension) roli uniwersytetu publicznego o praktyczną edukację i instruktaż, progresywni reformatorzy podkreślali m.in. rolę uniwersyteckich fachowców w szerzeniu nowoczesnych metod gospodarowania wśród rolników zamieszkujących tereny mogące znaleźć się pod eksperckim wpływem szkoły wyższej ${ }^{33}$. W międzywojennej Rzeczypospolitej nieco podobne idee propagował polski rząd widzący w miejscowych uniwersytetach i szkołach zawodowych szanse na podniesienie kultury rolnej na terenach wschodniego pogranicza ${ }^{34}$.

Jednak amerykański pomysł na szkołę rolniczą nieopodal Wilna wyróżniała rola, która przewidziano dla jej żeńskich absolwentek. Ekspertkami gospodarowania miały się stać kilkunastoletnie dziewczęta (szkołę kończyły 17-18-latki) podnoszące kulturę rolniczą wśród chłopów w małych wioskach. Pomysł zaproponowany przez Amerykanów byłby zapewne trudny do zrealizowania ze względu na nietradycyjność ról przewidzianych dla niewielkiej, bardziej od miejscowych chłopów, wykształconej grupki młodych dziewcząt.

${ }^{31}$ Ibidem, folder 947.11/08, Junior Red Cross Reports from the Field, April 5, 1922, s. 8.

${ }^{32}$ Terminem „progresywizm” określa się w USA zarówno epokę w dziejach (koniec XIX w., do czasów I wojny światowej), jak i działający w tym okresie oddolny ruch, którego celem było zreformowanie amerykańskiego życia społecznego, ekonomicznego i politycznego m.in. poprzez eliminację zjawisk postrzeganych jako patologiczne (np. korupcja, prostytucja, nadużywanie alkoholu, dominacja monopoli w gospodarce) i demokratyzację życia politycznego. Progresywne reformy miały być przeprowadzone w oparciu o zrobione wcześniej badania i zebrane statystyki wyjaśniające przyczyny patologii i możliwe rozwiązania problemów. Literatura na temat progresywizmu jest bardzo obszerna. Z nowszych opracowań warto wymienić: M. McGerr, A Fierce Discontent. The Rise and Fall of the Progressive Movement in America, 1870-1920, New York 2003; M. Flanagan, America Reformed. Progressives and Progressivisms, 1890s-1920s, Oxford 2006. Na temat prób przeniesienia progresywnych ideałów za granicę w pierwszych dekadach XX w. por. A. Dawley, Changing the World. American Progressives in War and Revolution, Princeton 2003; D.T. Rodgers, Atlantic Crossings. Social Politics in a Progressive Age, Cambridge 1998; J.T. Kloppenberg, Uncertain Victory. Social Democracy and Progressivism in European and American Thought, 1870-1920, New York 1988.

${ }^{33}$ F.M. Rosentreter, The Boundaries of the Campus. A History of the University of Wisconsin Extension Division, 1885-1945, Madison 1957; A.Ch. True, A History of Agricultural Extension Work in the United States, 1785-1923, Washington 1928.

${ }^{34}$ B. Winiarski, Polityka gospodarcza, wyd. 3, Warszawa 2006, s. 115-119. 
Nie wiemy też nic na temat prób jego rzeczywistego wprowadzenia w życie, podobnie jak w przypadku projektu wyposażania małych społeczności w warsztaty tkackie. Progresywny w swej koncepcji, również w wymiarze płciowym, pomysł na rozszerzenie wpływu miejscowej szkoły zawodowej na okoliczna ludność był raczej tylko dalekosiężnym, niezrealizowanym planem. W praktyce wspomagane przez Amerykanów szkolnictwo zawodowe ograniczało się do wytwarzania potrzebnych szkołom i sierocińcom mebli przez chłopców oraz szycia i robienia na drutach przez dziewczynki.

Omawiając inicjatywy szkolne CKM, przejęte następnie przez koła młodzieży PCK, nie można nie wspomnieć o jeszcze jednym wychowawczo i ideowo istotnym projekcie: międzynarodowej korespondencji międzyszkolnej. Wymiana listów, albumów i innych przedmiotów, np. lalek, dokonywana przez dzieci z USA i II RP, a następnie także z innych krajów, stała się od początku lat dwudziestych XX w. składową częścią aktywności polskich kół młodzieży. Ich liderzy, podobnie jak przywódcy CKM w Stanach Zjednoczonych, postrzegali międzynarodową korespondencję międzyszkolną jako narzędzie mające pomóc w osiagnięciu globalnego pokoju i przyjaźni pomiędzy narodami dzięki wychowaniu pokolenia kosmopolitycznych patriotów.

Wymiana listów i albumów między dziećmi z różnych krajów stanowiła w międzywojniu składowy element działalności globalnego ruchu kół młodzieży, w którym uczestniczyły krajowe organizacje Czerwonego Krzyża. W II Rzeczypospolitej doszło do niej po raz pierwszy w 1922 r. Tak opisywano ten moment w książeczce celebrujacej piętnastolecie polskiej organizacji:

Inicjatywę do tej akcji dała w swoim czasie młodzież amerykańska, przesyłając dzieciom polskim razem z darami gwiazdkowymi serdeczne, pełne ciepła liściki. Należało więc na nie odpowiedzieć, a za dary podziękować choćby jakaśs robótka, opisem życia szkoły, miasta, kraju rodzinnego. I tak powstała - korespondencja międzyszkolna. Najpierw z Ameryka, a potem z innymi krajami ${ }^{35}$.

W momencie wycofywania się ACK z Polski w 1923 r. wymiana listów i albumów pomiędzy dziećmi z innych krajów była prowadzona na niewielka skalę. Korespondencję wysyłano do szkół w pięciu państwach, w tym do Stanów Zjednoczonych; polskie koła młodzieży nadały za granicę 26 albumów i listów, otrzymały zaś $46^{36}$. Według amerykańskiej organizacji był to jednak ten element działalności, na którym lokalny CKM powinien się przede wszystkim skupić w kolejnych latach swojej aktywności, po opuszczeniu II Rzeczypospolitej przez ACK ${ }^{37}$. Postulatowi temu stało się zadość: w połowie lat trzydziestych XX w. koła młodzieży w II RP wysyłały i otrzymywały setki listów od uczniów z zagranicy i korespondowały z najmłodszymi z ok.

\footnotetext{
${ }^{35}$ Nasza praca..., s. 22.

${ }^{36}$ Ibidem.

${ }^{37}$ NARA, ARC, box 862, folder 947.11/08, Memorandum made for JRC by Miss Jones.
} 
50 krajów. Polska organizacja była jednym z najbardziej aktywnych oddziałów Czerwonego Krzyża na tym polu na skalę światowa ${ }^{38}$.

Pierwsze listy od amerykańskich kolegów polskie dzieci dostały i następnie na nie odpowiedziały $\mathrm{w}$ momencie świeżych jeszcze wspomnień z niedawno zakończonej wojny z Rosja Radziecka, której reminiscencje obecne sa np. w korespondencji z dotkniętego w 1920 r. konfliktem zbrojnym Lublina. Pisząc o swoich wojennych impresjach, jeden z miejscowych uczniów podkreślał, że to obrazy rannych bolszewików, bez części ciała czy też bez kończyn, wywarły na nim najbardziej bolesne wrażenie. „Współczułem tym cierpiącym ludziom" 39 - dodawał w liście wysyłanym do dzieci ze Stanów Zjednoczonych. Inny uczeń z lokalnej szkoły dzielił się wspomnieniami dotyczącymi reakcji lublinian na widok żołnierzy Armii Czerwonej:

Kiedy bolszewicy weszli do Polski... ludzie rozmawiali o nich jako o mordercach... Więc, moi drodzy amerykańscy przyjaciele, jak tylko pojawiły się pociagi z pojmanymi bolszewikami, ludzie pośpieszyli by ich zobaczyć, ale wtedy zobaczyli, że byli oni tak biedni i w takich łachmanach, że poczuli dla nich współczucie. Pewne kobiety ugotowały im coś, a inne dały im chleb ${ }^{40}$.

Opisy radzieckich żołnierzy, uczłowieczanych przez współczujące im lubelskie dzieci, nieprzypadkowo znalazły się w listach wysyłanych do najmłodszych ze Stanów Zjednoczonych. Na początku lat dwudziestych XX w. korespondencja pomiędzy szkołami w USA i II RP nie stanowiła spontanicznej wymiany listów, lecz była aranżowana, kontrolowana, kształtowana i stymulowana przez liderów CKM. W warstwie deklaracji nauczyciele mieli zostać zachęceni, aby wysyłać zwyczajne prace dzieci ${ }^{41}$. W rzeczywistości jednak Amerykanie z CKM selekcjonowali i wybierali, co ma dotrzeć do Stanów Zjednoczonych, decydując, kiedy korespondencja nadawała się, a kiedy nie, do przekazania ${ }^{42}$. Miejscowym uczniom i nauczycielom sugerowano też tematy, które były warte poruszenia w listach: dzieje Polski, w tym ważne dla kraju osoby i wydarzenia historyczne, opisy pięknych miejsc i krajobrazu w II RP, przede wszystkim z okolic zamieszkałych przez uczniów, polski przemysł i bogactwa naturalne. Dzieci miały również opisywać swoja codzienność, przede wszystkim szkolna. Zachęcano je także do dzielenia się wojennymi wspomnieniami i doświadczeniami ${ }^{43}$. Motywy te pojawiały się w międzynarodowej korespondencji przez całe międzywojnie, stanowiąc główny trop w listach

\footnotetext{
${ }^{38}$ Nasza praca..., s. 22; M. Bortnowska, Korespondencja międzyszkolna Kót Młodzieży Czerwonego Krzyża, Warszawa 1934, s. 4-5.

${ }^{39}$ NARA, ARC, box 862, folder 947.11/08, „Impressions of the Bolshevik War”.

${ }^{40}$ Ibidem, „Polish Children to American Children” - Lublin, March 2, 1922.

${ }^{41}$ Ibidem, Memorandum made for JRC by Miss Jones.

${ }^{42}$ Ibidem, Junior Red Cross Reports from the Field, April 5, 1922, s. 5.

${ }^{43}$ Ibidem, Memorandum made for JRC by Miss Jones.
} 
wymienianych przez małe Polki i Polaków z dziećmi z kilkudziesięciu krajów na kilku kontynentach ${ }^{44}$.

Powyższa charakterystyka prowadzi nas do trzech głównych, wzajemnie ze sobą powiązanych celów międzynarodowej korespondencji międzyszkolnej. Pierwszym z nich, jak określa to liderka kół młodzieży w II Rzeczypospolitej - M. Bortnowska, było „propagowanie Polski”45. Drugim: budowanie i kultywowanie przyjaźni pomiędzy dziećmi z różnych krajów. Trzeci zaś, używając terminu amerykańskiej historyczki Julii Irwin, stanowiło stworzenie globalnej generacji „kosmopolitycznych patriotów”46, zamieszkujących nie tylko Polskę czy Stany Zjednoczone, lecz również pochodzących z Niemiec, kraju według działaczy ACK odpowiedzialnego za rozpętanie wojny światowej.

„Propagowanie” własnego kraju przez dzieci uczestniczące w międzynarodowej korespondencji międzyszkolnej jest warte przyjrzenia się chociażby ze względu na obrazy Polski, Stanów Zjednoczonych czy też innych państw, stwarzane w ramach wymiany listów. Albumy i przedmioty przekazywane za granicę miały - według Bortnowskiej - „rozpraszać fałszywe pojęcia nagromadzone w młodocianych główkach”, a także sprawić, by odrębności między poszczególnymi krajami były przyjmowane „z zainteresowaniem”47. Wydaje się, że lalki górali i łowiczanek wysłane z Polski do USA spełniały przede wszystkim to drugie zadanie. W mniejszym stopniu zaś przyczyniały się one do pełnego wglądu w wieloaspektowość wieloreligijnego i wieloetnicznego kraju, jakim w międzywojniu była II Rzeczpospolita. Podobnie zapewne działo się w przypadku dość stereotypowych przedstawień Indian z Dakoty przekazywanych z USA do II RP ${ }^{48}$.

Wzajemne poznanie się poprzez korespondencję międzyszkolną miało prowadzić do drugiego kluczowego celu realizowanego poprzez wymianę listów: zbudowania międzynarodowej przyjaźni oraz poczucia wspólnotowości pomiędzy dziećmi z różnych krajów ${ }^{49}$. Zadanie te stawało się z perspektywy liderów CKM szczególnie istotne w kontekście powojennej materialnej pomocy Stanów Zjednoczonych dla krajów Europy. Wsparcie materialne doprowadziło według Amerykanów z CKM do nierówności i nierównowagi w relacjach pomiędzy obywatelami USA i państw Starego Kontynentu: pierwsi z nich stali się darczyńcami i dobroczyńcami, drudzy zaś zostali postawieni w pozycji odbiorców amerykańskiej pomocy. Międzynarodowa korespondencja międzyszkolna miała wprowadzić do relacji pomiędzy amerykańskimi i europejskimi dziećmi

\footnotetext{
${ }^{44}$ M. Bortnowska, op. cit., s. 11-12.

${ }^{45}$ Ibidem, s. 12.

${ }^{46}$ J.F. Irwin, Teaching „Americanism with a World Perspective”..., s. 257.

${ }^{47}$ M. Bortnowska, op. cit., s. 7.

${ }^{48}$ Nasza praca..., s. 23, 27.

${ }^{49}$ M. Bortnowska, op. cit., s. 5; S. Glassford, Practical Patriotism. How the Canadian Junior Red Cross and Its Child Members Met the Challenge of the Second World War, „Journal of the History of Childhood and Youth" 2014, vol. VII, no. 2, s. 220.
} 
elementy równości i obopólnego szacunku, wywodzących się z wzajemnego poznania oraz postulowanego dzielenia zbioru ideałów propagowanych przez koła młodzieży ${ }^{50}$.

Pochodzący ze Stanów Zjednoczonych zbiór ideałów, narodzony w kręgach tamtejszego CKM, został, jak już wspomniałam, nazwany przez Irwin „kosmopolitycznym patriotyzmem”. Powstał on i funkcjonował w międzywojniu jako alternatywa dla ideologii komunizmu i faszyzmu. Ponadto, jak podkreśla Irwin, „kosmopolityczny patriotyzm” miał być przeciwwagą dla „narodowego patriotyzmu" i wiary w amerykańska wyjątkowość, propagowanych po wojnie w USA przez wiele środowisk starających się wpłynąć na edukację szkolna. W kołach młodzieży w Stanach Zjednoczonych, jak zwraca uwagę Irwin, starano się wytworzyć pośród najmłodszego pokolenia obywateli USA nowa, bardziej kosmopolityczna, lecz nadal amerykańską tożsamość międzynarodowa ${ }^{51}$. Zadania stojące przed szkołami w tym aspekcie były - według liderów CKM - niezwykle istotne ze względu na generalny brak myślenia w kategoriach kosmopolitycznego patriotyzmu wśród dorosłych, w tym wśród rodziców kształtujących przyszłe pokolenie Amerykanów ${ }^{52}$.

Kosmopolityczny patriotyzm był według liderów CKM w USA szczególnie potrzebny wśród Europejczyków uważanych za odpowiedzialnych za rozpętanie największego konfliktu zbrojnego w dziejach nowożytnych. Przekonanie o jego potrzebie podzielali również polscy liderzy CKM, szerząc je nie tylko w okresie tuż powojennym, lecz również w kolejnych latach, już po wycofaniu się Amerykanów z II Rzeczypospolitej. Postulaty polskiego edukatora i reformatora szkolnego Kazimierza Kujawskiego, wielkiego entuzjasty kół młodzieży ${ }^{53}$, szły w tym aspekcie jeszcze dalej niż amerykańskie wzorce. Według jednej z pracownic ACK: Elsie Graves Benedict, Kujawski widział w kołach młodzieży i międzynarodowej korespondencji międzyszkolnej narzędzia, dzięki którym, w długiej perspektywie, „nie będzie narodowości (nationality), lecz po prostu ludzkość (humanity)" ${ }^{4}$. Dla Benedict Kujawski stanowił modelowy przykład pracownika Czerwonego Krzyża, podzielającego pogląd, że „koła młodzieży są podstawowym środkiem ulepszenia świata i częścią jego obecnej ewolucji”" Polski reformator był m.in. zwolennikiem korespondencji pomiędzy szkołami

50 S. Glassford, op. cit., s. 221; J.F. Irwin, Teaching „Americanism with a World Perspective”..., s. 269.

${ }^{51}$ J.F. Irwin, Teaching „Americanism with a World Perspective”..., s. 257.

${ }^{52}$ Ibidem, s. 258.

${ }^{53} \mathrm{~W}$ latach dwudziestych XX w. Kujawski pełnił funkcję dyrektora polskiego CKM. Był również autorem publikacji propagujących jego działania. Por. np.: K. Kujawski, Koła Młodziė̇y Czerwonego Krzyża, Warszawa 1929; idem, O Kołach Młodzieży Czerwonego Krzyża, Warszawa 1929.

${ }^{54}$ NARA, ARC, box 862, folder 947.11/01, Elsie Graves Benedict to R.P. Lane, Report on Junior Red Cross, Poland, May 16, 1922, s. 6.

55 Ibidem. 
z II Rzeczypospolitej i Niemiec ${ }^{56}$, w międzywojniu rzeczywiście prowadzonej przez dzieci z obu krajów ${ }^{57}$. Zgodne z poglądami Kujawskiego, jak i z ideami szerzonymi przez Amerykanów z CKM, były również przywoływane już pełne współczucia opisy bolszewików, wysłane z Lublina do Stanów Zjednoczonych w 1922 r. Wybór właśnie takich listów czy też korespondencja z dziećmi z kraju, który wcześniej należał do grupy państw Trójporozumienia, jasno wskazywał, że wrogość i konflikt powinny zostać zastapione przez międzynarodowa przyjaźń i kooperację. W wizji Amerykanów i w wyobrażeniach polskich liderów CKM, takich jak Kujawski czy Bortnowska, dzięki korespondencji międzyszkolnej dzieci z II Rzeczypospolitej miały zasilić szeregi nowego zgodnego i pokojowego pokolenia Europejczyków odpowiedzialnych za przyszłe losy świata ${ }^{58}$.

Korespondencja międzyszkolna w polskim kontekście posiadała jeszcze jeden istotny aspekt: była prowadzona nie tylko na niwie międzynarodowej, lecz również krajowej. Lokalny wymiar inicjatywy charakteryzował, co może być dość zaskakujące, podobny cel: zbudowanie przyjaźni pomiędzy dziećmi z dalekich zakątków II Rzeczypospolitej. Jak pisano na stronach jubileuszowego wydawnictwa CKM: „Warszawa ma swoich przyjaciół na Polesiu, Wołyń prowadzi wymianę albumów z Pomorzem i w ten sposób młodzież różnych, odległych od siebie dzielnic poznaje się" ${ }^{59}$. Wzajemne zaznajamianie się dzieci z różnych części wieloetnicznej i wieloreligijnej II Rzeczypospolitej skłania do dokładnego przyjrzenia się patriotyzmowi propagowanemu przez CKM w Polsce. We wspominanym już artykule o amerykańskim CKM Irwin używa zamiennie dwóch pojęć, definiując idee propagowane przez amerykańskie koła młodzieży jako „kosmopolityczny patriotyzm” lub jako „kosmopolityczny nacjonalizm”. W języku angielskim „kosmopolityczny nacjonalizm” (cosmopolitan nationalism) może być traktowany jako synonim używanego do tej pory przeze mnie „kosmopolitycznego patriotyzmu” (cosmopolitan patriotism), lepiej moim zdaniem w języku polskim wyrażającego idee propagowane przez koła młodzieży. Pamiętajacc o odmiennym semantycznie znaczeniu tych dwóch słów, zastanówmy się jednak, czy pewne narodowe, czy też nacjonalistyczne elementy występowały w działaniach CKM w powojennej Rzeczypospolitej. Odpowiedź na to pytanie pozwoli być może także na wpisanie działań kół młodzieży we wspominane już międzywojenne polskie koncepcje „wychowania narodowego" i „wychowania państwowego”.

Postrzeganie kwestii narodowych czy tė̇ etnicznych na rubieżach II Rzeczypospolitej przez humanitarystów z USA pokazuje opisywane przez Amerykanów wydarzenie majace miejsce na samym początku pomocy materialnej dla

\footnotetext{
${ }^{56}$ Ibidem.

${ }^{57}$ M. Bortnowska, op. cit., s. 14.

${ }^{58}$ Ibidem; J.F. Irwin, Teaching „Americanism with a World Perspective”..., s. 256-258.

${ }^{59}$ Nasza praca..., s. 24.
} 
szkół na wschodnich terenach II RP. Opisując we wrześniu 1921 r. transport sfinansowanych przez amerykańskich uczniów książek, jeden z działaczy CKM wspominał trudne warunki logistyczne i nieustanne zatrzymywanie się samochodów przewożących tysiące woluminów na pagórkowatym terenie: „Podczas jednego z przystanków, podeszło do nas kilku chłopów, by pomóc nam przedostać się przez drogę. Jeden z nich błagał o elementarz, aby mógł się nauczyć czytać. Niestety był Białorusinem i nie znał języka, w którym książki były napisane" ${ }^{60}$.

Sfinansowane przez amerykańskie dzieci elementarze, wysłane na tereny jeszcze kilka lat wcześniej wchodzące w obręb Imperium Rosyjskiego, przeznaczone były do nauki pisania i czytania w języku mającym stać się oficjalna mową wszystkich grup etnicznych i religijnych odrodzonej niedawno II RP. Przygotowanie podręczników dla dzieci w wieku szkolnym tylko w języku polskim było zgodne z ideami oświatowymi dominującymi na początku lat dwudziestych XX w. zarówno w Stanach Zjednoczonych, jak i w II Rzeczypospolitej. W USA, na fali powojennej ksenofobii i antyradykalizmu, dążono do stworzenia bardziej jednolitego społeczeństwa mówiącego wspólnym językiem i definiującego się jako amerykańscy obywatele, a nie członkowie różnych grup imigranckich czy etnicznych. Jedną z instytucji mających pomóc w realizacji tego założenia była szkoła ${ }^{61}$. Narodotwórcze postulaty odwołujące się do patriotyzmu, tradycji i polskiej religii (definiowanej jako katolicyzm) przeważały w powojennym okresie w nurtach wychowawczych i oświatowych II Rzeczypospolitej ${ }^{62}$. Uwzględniając potrzeby edukacyjne tylko pewnych społeczności etnicznych i przygotowując elementarze wyłącznie $\mathrm{w}$ języku polskim, amerykańscy działacze z CKM - intencjonalnie czy też nie - popierali koncepcję „wychowania narodowego” dominującego ówcześnie w oświacie w II RP. Brak podręczników do czytania w języku białoruskim oznaczał również, że zgodnie z polityką narodowościową powojennej Rzeczypospolitej dzieci

${ }^{60}$ NARA, ARC, box 862, folder 947.11/08, Junior Red Cross in Baranowicze District, Poland, Sept 1921.

${ }^{61}$ J.F. Irwin, Teaching „Americanism with a World Perspective”..., s. 255; J. Mirel, Patriotic Pluralism. Americanization Education and European Immigrants, Cambridge MA 2010, passim.

${ }^{62}$ W II RP dopiero od 1924 r. uwzględniono postulaty mniejszości narodowych, umożliwiając zakładanie we wschodnich województwach szkół oferujących zajęcia w językach innych niż polski. Zajęcia takie mogły być wprowadzone do publicznej szkoły powszechnej na żądanie rodziców co najmniej 40 dzieci. W latach dwudziestych XX w., wbrew zobowiązaniom z traktatu mniejszościowego, państwo nie zakładało szkół publicznych, w których językiem wykładowym byłby jeden $\mathrm{z}$ języków żydowskich (hebrajski lub jidysz); w drugiej połowie lat dwudziestych i w latach trzydziestych XX w. zaczęto ograniczać, a nawet likwidować szkoły z wykładowym ukraińskim i białoruskim. Tendencje te dotykały przede wszystkim uczniów białoruskich, z których praktycznie wszyscy uczyli się w szkołach z językiem polskim jako wykładowym. S. Mauersberg, Komu służyła szkoła w Drugiej Rzeczpospolitej? Społeczne uwarunkowania dostępu do oświaty, Wrocław-Gdańsk 1988, s. 69-74. 
niepiśmiennego chłopa pomagającego w transporcie książek uczyły się czytać i pisać po polsku ${ }^{63}$.

Obraz II Rzeczypospolitej jako kraju jednolitego etnicznie i wyznaniowo szerzyła też międzynarodowa korespondencja międzyszkolna. Listy i przedmioty wysyłane z Rzeczypospolitej nie przedstawiały białoruskiego czy też ukraińskiego folkloru, tylko etnicznie polski: góralski, łowicki czy kujawski. Żadne ze źródeł nie wskazuje na to, że koła młodzieży były zakładane w szkołach żydowskich lub też $\mathrm{w}$ tych prowadzonych przez mniejszości narodowe i etniczne. Być może dzieci wyznawców judaizmu stykały się z CKM, uczęszczając do szkół powszechnych, lecz ponownie - podobnie jak w przypadku mniejszości ukraińskiej i białoruskiej - albumy i przedmioty wysyłane z Polski nic nie mówiły o żydowskiej tradycji czy zwyczajach. Podobnie jak w przypadku innych amerykańskich powojennych inicjatyw pomocowych i filantropijnych, także i ten projekt charakteryzował się $\mathrm{w}$ dużej mierze segregacją etniczną i religijną.

$$
* * *
$$

W latach po I wojnie światowej amerykański Czerwony Krzyż Młodzieży szerzył w II Rzeczypospolitej spójną i dalekosiężną wizję wychowawcza i edukacyjna, której celem było doprowadzenie do znaczacych zmian politycznych nie tylko na gruncie lokalnym, lecz także międzynarodowym. Dzieci z polskich szkół, działające w kołach młodzieży zakładanych przez CKM, postrzegane były przez Amerykanów jako członkowie globalnej wspólnoty młodych patriotycznych kosmopolitów, których generacja miała zapobiec wybuchowi kolejnej wojny światowej. Jako młodzi obywatele kraju usytuowanego koło komunistycznej Rosji, polskie dzieci poprzez uczestnictwo w kołach młodzieży i „służbę" innym miały również nabywać istotne cechy niezbędne dla zakorzenienia się i przetrwania porządku kapitalistycznego w Europie Środkowo-Wschodniej.

Transfer amerykańskich idei propagowanych przez CKM do II RP nie zawsze jednak przebiegał pomyślnie, przede wszystkim ze względu na odmienne warunki ekonomiczne w obu krajach. W powojennej Polsce upowszechnianie etyki wytwórczości, oszczędności i przedsiębiorczości nie mogło się odbywać, tak jak w USA, w opozycji do coraz bardziej dominujacego w Stanach w latach dwudziestych XX w. konsumeryzmu. Wytwarzanie ubrań czy uprawa warzyw przez polskie dzieci zapewniały im przede wszystkim dostęp do podstawowych produktów często nieosiagalnych w okresie tuż po wojnie. Propagując kosmopolityczny patriotyzm, szerzony m.in. przez międzynarodową korespondencję

${ }^{63} \mathrm{Na}$ temat polityki narodowej II RP zob. A. Chojnowski, Koncepcje polityki narodowościowej rzqdów polskich w latach 1921-1939, Wrocław 1979. Na temat szkolnictwa i mniejszości narodowych zob. S. Mauersberg, Szkolnictwo powszechne dla mniejszości narodowych w Polsce $w$ latach 1918-1939, Wrocław 1968. 
międzyszkolna, CKM nie brał jednocześnie pod uwagę zróżnicowania etnicznego i wyznaniowego II Rzeczypospolitej. Treści widoczne w wymienianych przez uczniów listach i innych materiałach, przygotowanie podręczników tylko w języku polskim, brak prób dotarcia do szkół dla mniejszości pokazuja, że działania amerykańskiego, a następnie polskiego CKM wpisywały się oraz popierały koncepcję wychowania narodowego dominującego w oświacie w II RP w latach po I wojnie światowej.

\section{Streszczenie}

Artykuł poświęcony jest działaniom amerykańskiego Czerwonego Krzyża Młodzieży w Polsce po I wojnie światowej. Przedstawiono w nim główne inicjatywy podejmowane przez organizację w szkołach w II RP, takie jak zakładanie kół młodzieży, pomoc ubogim i nieuprzywilejowanym uczniom określaną jako „służba”, zakładanie szkolnych ogródków warzywnych czy wymiana listów w ramach międzynarodowej korespondencji międzyszkolnej. W artykule ukazano również idee wychowawcze i edukacyjne szerzone przez CKM, mające doprowadzić do znaczących zmian politycznych zarówno na gruncie lokalnym, jak i międzynarodowym. Podkreślono, że dzieci z polskich szkół, działające w kołach młodzieży zakładanych przez CKM, postrzegane były przez Amerykanów jako członkowie globalnej wspólnoty młodych patriotycznych kosmopolitów, których generacja miała zapobiec wybuchowi kolejnej wojny światowej. Jako młodzi obywatele kraju usytuowanego koło komunistycznej Rosji, polskie dzieci poprzez uczestnictwo w kołach młodzieży i „służbę” innym miały również nabywać istotne cechy niezbędne dla zakorzenienia się i przetrwania porządku kapitalistycznego w Europie Środkowo-Wschodniej.

\section{The "service," capitalism, and "cosmopolitan patriotism:" the American Junior Red Cross in the Second Polish Republic}

The article is devoted to the operations of the American Junior Red Cross in Poland after the First World War. It presents the main types of initiatives undertaken by the organisation in schools of the Second Polish Republic, such as the creation of circles of interest, aid to the poor and unprivileged students, called "the service," planting of school vegetable gardens, or exchange of letters within the international interschool correspondence. The article also presents the educational ideals propagated by the American Junior Red Cross, which were to lead to significant political changes both at the national, and at the international level. Attention was paid to the fact that Polish children active in youth interest groups and circles organised by the American Junior Red Cross were regarded by the Americans as members of the universal community of young patriotic cosmopolitans, who were to prevent the outbreak of another world war. As young citizens of the country neighbouring with communist Russia, through their activity in youth circles and the "service," Polish children were to acquire important traits and attributes necessary for the capitalist order to get established and endure in Central Eastern Europe. 


\section{Bibliografia}

Araszkiewicz F.W., Ideały wychowawcze Drugiej Rzeczpospolitej, Warszawa 1978.

Chojnowski A., Koncepcje polityki narodowościowej rzqdów polskich w latach 1921-1939, Wrocław 1979.

Dawley A., Changing the World. American Progressives in War and Revolution, Princeton 2003.

Dulles F.R., The American Red Cross. A History, New York 1950.

Flanagan M., America Reformed. Progressives and Progressivisms, 1890s-1920s, Oxford 2006.

Glassford S., Practical Patriotism. How the Canadian Junior Red Cross and Its Child Members Met the Challenge of the Second World War, „Journal of the History of Childhood and Youth" 2014, vol. VII, no. 2, s. 219-242.

Hayden-Smith R., „Soldiers of the Soil”. The Work of the United States School Garden Army during World War, „Applied Environmental Education and Communication” 2007, vol. VI, no. 1, s. 19-29.

Hutchinson J.F., The Junior Red Cross Goes to Healthland. „American Journal of Public Health" 1997, vol. LXXXVII, no. 11, s. 1816-1823.

Irwin J.F., Making the World Safe. The American Red Cross and the Nation's Humanitarian Awakening, Oxford-New York 2013.

Irwin J.F., Sauvons les Bébés. Child Health and U.S. Humanitarian Aid in First World War Era, „Bulletin of the History of Medicine” 2012, vol. LXXXVI, no. 1, s. 37-65.

Irwin J.F., Teaching „Americanism with a World Perspective”. The Junior Red Cross in the U.S. Schools from 1917 to the 1920s, „History of Education Quarterly” 2013, vol. LIII, no. 3 , s. $255-279$.

Kessler-Harris A., Out to Work. A History of Wage-Earning Women in the United States, New York-London 2003.

Kloppenberg J.T., Uncertain Victory. Social Democracy and Progressivism in European and American Thought, 1870-1920, New York 1988.

Kohlstedt S.G., „A Better Crop of Boys and Girls”. The School Gardening Movement, 1890-1920, „History of Education Quarterly” 2008, vol. XLVIII, no. 1, s. 58-93.

Little B., A Child's Army of Millions. The American Junior Red Cross, w: Children's Literature and Culture of the First World War, ed. L. Paul et al., New York-London 2015, s. $283-300$.

Mauersberg S., Komu stużyła szkoła w Drugiej Rzeczpospolitej? Społeczne uwarunkowania dostępu do oświaty, Wrocław-Gdańsk 1988.

Mauersberg S., Szkolnictwo powszechne dla mniejszości narodowych w Polsce $w$ latach 1918-1939, Wrocław 1968.

McGerr M., A Fierce Discontent. The Rise and Fall of the Progressive Movement in America, 1870-1920, New York 2003.

Mirel J.E., Patriotic Pluralism. Americanization Education and European Immigrants, Cambridge, MA 2010.

Murray R.K., The Politics of Normalcy. Governmental Theory and Practice in the Harding-Coolidge Era, New York 1973.

Norton M.B., Liberty's Daughters. The Revolutionary Experience of American Women, 1750-1800, Ithaca, NY 1996.

Rodgers D.T., Atlantic Crossings. Social Politics in a Progressive Age, Cambridge 1998.

Rosentreter F.M., The Boundaries of the Campus. A History of the University of Wisconsin Extension Division, 1885-1945, Madison 1957.

Sadowska J., Ku szkole na miarę Drugiej Rzeczypospolitej. Geneza, założenia i realizacja reformy Jędrzejewiczowskiej, Białystok 2001.

Schoenbrenner J., Walka o demokratyczna szkote polska w latach 1918-1922, Warszawa 1963. 
Tomes N., The Gospel of Germs. Men, Women, and the Microbe in American Life, Cambridge 1999.

Trelstad B., Little Machines in Their Gardens. A History of School Gardens in America, 1891-1920, „Landscape Journal” 1997, vol. XVI, no. 2, s. 161-173.

Weber M., Etyka protestancka a duch kapitalizmu, tłum. B. Baran, P. Miziński, Warszawa 2010.

Bi g r a m: Sylwia Kuźma-Markowska - dr; adiunkt w Ośrodku Studiów Amerykańskich Uniwersytetu Warszawskiego. Zainteresowania naukowe dotyczą historii społecznej i kulturowej Stanów Zjednoczonych i Polski w XX w., społecznej historii medycyny i historii kobiet. Jest autorką m.in. książki Zdrowe matki, chciane dzieci. Ruch kontroli urodzeń $w$ stanie Illinois (1923-1941), Warszawa 2009. Obecnie pracuje nad monografia o amerykańskich inicjatywach humanitarnych i filantropijnych $\mathrm{w}$ międzywojennej Polsce. E-mail: s.kuzma@uw.edu.pl. 